
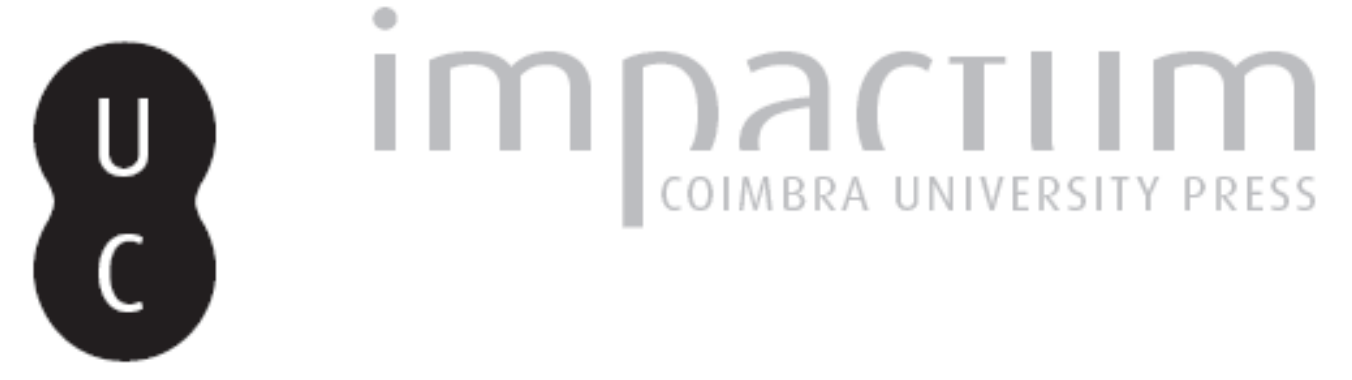

\title{
Fifth European Intensive Course on Applied Geomorphology ou o ponto da situação dos estudos sobre riscos naturais no sul de Portugal
}

Autor(es): Rebelo, Fernando

Publicado por: Associação Portuguesa de Riscos, Prevenção e Segurança

URL persistente:

URI:http://hdl.handle.net/10316.2/40172

DOI:

DOI:https://doi.org/10.14195/1647-7723_3_9

Accessed : $\quad$ 26-Apr-2023 09:46:48

A navegação consulta e descarregamento dos títulos inseridos nas Bibliotecas Digitais UC Digitalis, UC Pombalina e UC Impactum, pressupõem a aceitação plena e sem reservas dos Termos e Condições de Uso destas Bibliotecas Digitais, disponíveis em https://digitalis.uc.pt/pt-pt/termos.

Conforme exposto nos referidos Termos e Condições de Uso, o descarregamento de títulos de acesso restrito requer uma licença válida de autorização devendo o utilizador aceder ao(s) documento(s) a partir de um endereço de IP da instituição detentora da supramencionada licença.

Ao utilizador é apenas permitido o descarregamento para uso pessoal, pelo que o emprego do(s) título(s) descarregado(s) para outro fim, designadamente comercial, carece de autorização do respetivo autor ou editor da obra.

Na medida em que todas as obras da UC Digitalis se encontram protegidas pelo Código do Direito de Autor e Direitos Conexos e demais legislação aplicável, toda a cópia, parcial ou total, deste documento, nos casos em que é legalmente admitida, deverá conter ou fazer-se acompanhar por este aviso.

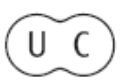




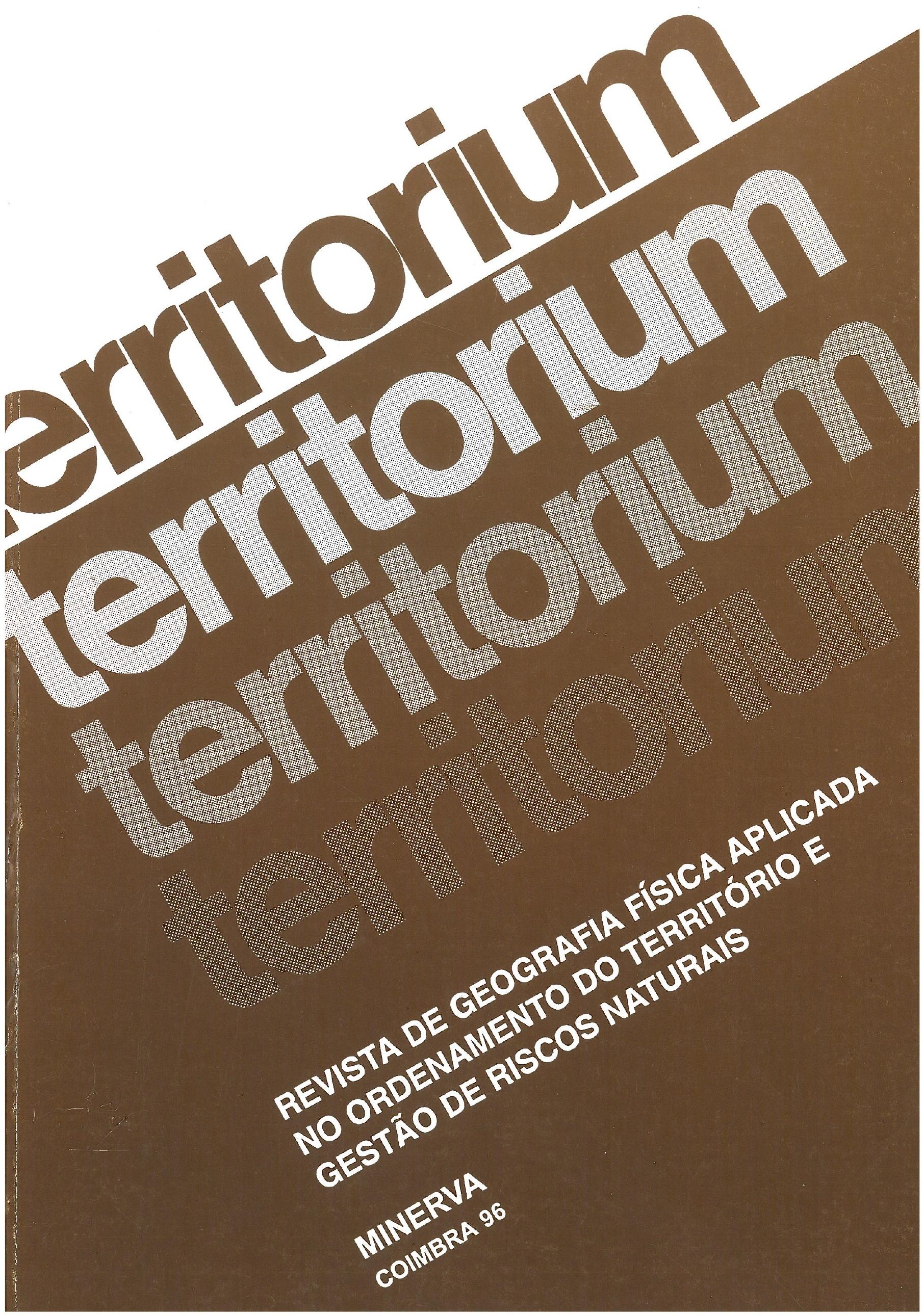


Universidade Louis Pasteur, de Strasbourg, e foram traduzidos por Maria Helena Dias - "Transformações cartográficas espaciais e anamorfoses", de Colette Cauvin (p. 267-310), e "A Cartografia e o computador", de Sylvie Rimbert (p. 311-344). Saliente-se que Colette Cauvin escolheu exclusivamente exemplos portugueses para ilustrar o seu texto, o que lhe dá, sem dúvida, uma maior força perante o leitor a que se destina (figuras 52 a 64), e que Sylvie Rimbert, tratando, uma vez mais, dos SIG, mostra claramente como, apesar da difusão de programas cartográficos para computadores, nem tudo está resolvido e ainda é possível fazer investigação em Cartografia distinguindo-se, assim, "novos amadores e novos cartógrafos" (p.337-339).

Dizer que todo este livro é muito importante para a geografia física aplicada ao ordenamento do território será um erro. No entanto, ele é de grande importância para todos os que estão interessados no ordenamento do território, não só pelos numerosos exemplos que apresenta, desde a cartografia de base à mais avançada cartografia temática, mas também pela descida ao pormenor na fundamentação, caracterização e perspectivas para ofuturoda cartografia geomorfológica e de riscos naturais, bem como dos Sistemas de Informação Geográfica (SIG).

\section{Fifth European Intensive Course on Applied Geomorphology ou o ponto da situação dos estudos sobre riscos naturais no sul de Portugal}

\section{Fernando Rebelo}

Com a participação de 45 geomorfólogos, oriundos das Universidades de Amsterdam, Bonn, Ferrara, Lisboa, Modena, Santander, Strasbourg, Utrecht, Wien e Zaragoza, e sob o patrocínio do Programa ERAMUS, realizou-se em Lisboa e no Algarve, entre 17 e 24 de Junho de 1996, um curso intensivo de Geomorfologia Aplicada.

A propósito deste curso e precisamente sob o título de Fifth European Intensive Course on Applied Geomorphology. Mediterranean and Urban Areas, foi editado, por António de Brum Ferreira e Gonçalo Teles Vieira, um conjunto de pequenos trabalhos que constituem um importante livro sobre riscos naturais no sul de Portugal (Lisboa, Faculdade de Letras da Universidade de Lisboa, 1996, 238 p.).

Após uma introdução assinada por M. Panizza e M. Soldati sobre os cursos intensivos ERASMUS, os três primeiros trabalhos referem-se jáà Geomorfologia de Portugal, mas são nitidamente de carácter introdutório - "Applied geomorphology in Mediterranean and urban areas: the example of Southern Portugal" (A. B. Ferreira), "Geomorphology of Portugal: long-term evolution and tectonic setting" (A. B. Ferreira) e "Geomorphology of Portugal: general aspects of the landforms" (D. B. Ferreira).

A primeira abordagem dos riscos naturais aparece no trabalho de A. B. Ferreira e J. L. Zêzere intitulado "Geodynamic hazards in Portugal" (p. 35-43). Salientam-se os riscos sísmicos, os movimentos de massa, as inundações e a erosão costeira. Segue-se um trabalho de Teresa Barata Salgueiro ("The urban development of Lisbon") que corresponde a uma apresentação da morfologia e da estrutura funcional da grande cidade que depois virá a ser estudada com pormenor no respeitante aos riscos naturais - "Notes for the characterization of the seismic vulnerability of building construction in Lisbon" (C. S. Oliveira), "Earthquake emergency planning and response. Application to the city of Lisbon" (I. Pais) e "Earthquakes in Lisbon's urban history. A theme for a guided visit" (I. Pais).

"Landslides in the north of Lisbon region" (p. 7989) é uma pequena síntese de José Luís Zêzere feita com base nas pesquisas que aí vem efectuando desde os anos 80 e que lhe permitiram recensear 597 casos de movimentos de massa, distribuidos por 5 tipos ("Shallow translational slides", "Translational slides", "Rotational slides", "Slides/falls due to lateral sapping", e "Complex movements") apenas em 5 áreas-amostra (Calhandriz, Fanhões, Trancão, Lousa e Loures).

Do mesmo Autor, seguem-se quatro pequenas notas de pormenor sobre outros tantos casos - "The Quinta da Boavista landslide. An example of mass movement in an ill-consolidated fill" (p. 91-93), "Mass movements in Fanhões area" (p. 95-99), "Mass movements and geomorphological hazard assessment in the Trancão valley, between Bucelas and Tojal" (p. 101-105) e "The multiple retrogressive slide of 
Casal Novo do Brejo. Back analisys of slope stability conditions" (p. 115-119). Entre as duas últimas notas posiciona-se uma breve, mas interessante análise, assinada por A. B. Ferreira, J. L. Zêzere e M. L. Rodrigues, de um grande movimento de massa ocorrido em 9 e 10 de Fevereiro de 1979 e já várias vezes apresentado à comunidade científica em Portugal e noestrangeiro pelos mesmos Autores - "The Calhandriz landslide" (p. 107-113).

Em todos os artigos sobre movimentos de massa salientam-se, acima de tudo, os esboços geomorfológicos que os acompanham. Mais aprofundados uns, mais simplificados, propositadamente, outros, eles são sempre oportunos e muito elucidativos.

Problemas ambientais são aflorados nos trabalhos seguintes, da autoria de Maria Luisa Rodrigues ("Morphostructural conditions, slope deposits and environmental problems in the Estremadura limestone massif (Portugal)", "The Minde depression: geomorphology and hydrologic features","Fórnia and Chão das Pias: karstification and quaternary slope evolution" e "Geomorphology and environmental hazards in the Alvados depression and karstic springs of river Lena"); entre os dois últimos, M. L. Rodrigues e J. L. Zêzere apresentam o estudo de um pequeno caso de movimento de massa - "The landslide of Boiça/ Feteira (Serro Ventoso)" (p. 143-145). Também aqui é a representação cartográfica que mais se salienta possibilitando uma leitura fácil e rápida dos diferentes trabalhos.

Catarina Ramos publica, a seguir, quatro pequenos trabalhos com origem mais ou menos próxima na sua tese de doutoramento (1) - "The natural regimes of

\footnotetext{
(1) Sobre a tese de doutoramento de Catarina Ramos, ver: F. REBELO, "A especialização como ideia força en quatro teses de doutoramento em Geografia Física defendidas em 1994 e $1995^{\prime \prime}$. Teritorium, 2, 1995, p. 65-66.
}

portuguese rivers", "Hydrologic diversity in the Tagus" portuguese basin", "The floods of the river Tagus" e "Floods and inundations in the low valley of the river Maior".

Muito sintético e curto é o artigo seguinte, da autoria de Suzanne Daveau, intitulado "The Sorraia valley. Topics for a guided visit" (p. 185-189) - fala da evolução holocénica e histórica da planície aluvial, da dificuldade de travessia do rio, de Coruche, do uso da terra e dos problemas actuais como, por exemplo, os riscos de inundação.

Igualmente muito curto é o artigo assinado pela equipa portuguesa da EUROflood (F. N. Correia, M. G. Saraiva, J. Rocha, F. Bernardo e I. Ramos) "Public perception of flood risk and flood defence policies. The example of Setúbal" (p. 191-197).

Os últimos trabalhos deste livro referem-se ao litoral do Alentejo e do Algarve - "The Alentejo and Algarve coasts in the portuguese framework" (A. R. Pereira), "Vulnerability of a man-made coastal section. The example of the bay of Sines" (A. R. Pereira), "Rock coast of Pessegueiro (SW Portugal). Present-day evolution" (M. Neves), "The coastal area near Vila Nova de Milfontes" (A. R. Pereira), "Recent evolution of the bay of Lagos after a heavy anthropogenic intervention" (A. R. Pereira), "Vulnerability of the beach-cliff system of Praia da Rocha" (A. R. Pereira e M. Gomes) e "The beach-cliff system of Vale do Lobo" (A. R. Pereira).

Além da já referida ilustração no que diz respeito aos movimentos de massa, não pode deixar de destacar-se o número elevado de cartogramas e gráficos que enriquece o livro no seu conjunto, bem como alguns quadros e algumas fotografias incluidos em vários artigos. 


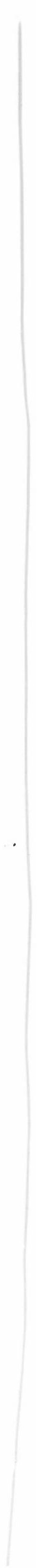

